\title{
Propaganda Instruments in Contemporary Campaigns: Comparison of Estonian Political Television Advertisements and Modern Television Commercials
}

\author{
Agu Uudelepp
}

\begin{abstract}
The author argues in the present article that although propaganda is considered mostly a tool of ideological communication suitable for use during wars or in totalitarian states, it is still used in contemporary democratic societies at peacetime and there are no major differences between employing instruments of propaganda in the public or the private sectors. The present analysis is based on the similarities and differences between Estonian political television advertisements and modern television commercials with an emphasis on the application of propaganda instruments. The author employed content analysis when studying the sample in which were 100 non-political and 84 political advertisements. This research shows that Estonian political television advertisements and international non-political television advertisements share some significant similarities: cognitive propaganda instruments are more widely employed than social or technological ones. The role of technological propaganda instruments is diminishing and such instruments are replaced by structural ones. A major difference is that, on average, there are more propaganda instruments per advertisement in political television advertisements than in non-political television advertisements, and technological propaganda instruments are not employed in non-political television advertisements.
\end{abstract}




\section{Introduction}

Attempts to influence the minds of others are as old as human communication (Taylor 2003:6). Many artefacts from prehistory and from earliest civilizations provide us with evidence that attempts were made to use the equivalent of modern-day propaganda techniques to communicate to the people the purported majesty and supernatural powers of rulers and priests (Jowett and O’Donnell 1999:48). Early texts written in hieroglyphs also bear symbols which describe history in the way useful for leaders (Pratkanis and Aronson 2001:11).

The term "propaganda" has distinctly religious origins. On 22 June 1622, Pope Gregory XV issued the Papal Bull Inscrutabili Diviniae establishing the Sacre Congregation de Propaganda Fide. ${ }^{1}$ The new congregation was colloquially called propaganda. (Jackall 1995:1)

So propaganda as a process is of ancient origin but as a term, it is of medieval origin. Still, no theoretical analysis of propaganda was made until after the World War I. Prior to the World War I, it was believed that developing a conditioned reflex was sufficient to influence people i.e. if a message is repeated frequently enough people will start believing it (Uudelepp 2005). The World Wars necessitated broadening of practical knowledge of propaganda because of the need to conduct wide scale propaganda campaigns. That gave the term "propaganda" negative connotation which it still has in democratic states.

Negative connotation means that it is politically incorrect to admit application of propagandistic tools in order to achieve the aims of an institution or organization. This in turn causes a controversial situation where the importance of a desired influence on target audiences is rising and, at the same time, the explicit application or demonstration of proven principles is not acceptable. There are several possible solutions to the contradiction: first, to abandon propaganda in modern societies; second, to develop other ways of influencing public opinion such as public relations; third, to rename the techniques formerly known as propagandistic and continue applying them. The author argues in the present article that although propaganda is considered mostly a tool of ideological communication suitable for use during wars or in totalitarian states, it is still used in contemporary democratic societies at peacetime and there are no major differences between employing instruments of propaganda in the public or the private sectors.

Several problems arise from this hypothesis. Considering the limited space of one article, it is impossible to analyze all the aspects of propaganda. Therefore, the research question is formulated as follows: what are the main similarities and differences between the application of propaganda instruments in political and non-political TV advertisements? The question can be divided into groups of more specific questions:

1. Are any propaganda instruments used?

2. If yes, are they applied only in politics or in other spheres, too?

3. If they are applied both in politics and other spheres, what are the specific aspects of the use of such instruments in various spheres?

The present analysis is based on the similarities and differences between Estonian political television advertisements and modern television commercials with an emphasis on the application of propaganda instruments. This constitutes a new approach to research into

\footnotetext{
${ }^{1}$ The Sacred Congregation of Disseminating Faith
} 
propagandistic messages in Eastern Europe. It is common to study the messages contained in advertisements or their influence (Kaid and Holtz-Bacha 1995:207). Context analysis of propaganda instruments in television advertisements is new in the Eastern European context.

Propaganda instruments are deliberate and functional instructions and ways of interaction to influence people. It is customary in the literature about propaganda to refer to the seven propaganda devices defined by the Institute for Propaganda Analysis in $1937^{2}$ : name calling, glittering generalities, transfer, testimonials, band wagon, card stacking and plain folks. Such a classification is not academic and the wording is also more suitable for popular sciences. The author aims at presenting in his article a more academic and theoretically sound abstraction of propaganda instruments.

\section{Methodology and sampling}

The current research is focused on the study of political and non-political television advertisements. There are two reasons for choosing television advertisements as the basis of the analysis. First, advertisements are the only form of mass communication over which political or business communicators have total control, i.e. each message is formulated and presented exactly as wanted (McNair 1995:95). Second, in most countries, television is the major channel of advertisements and most people consider it the major communicative link between politicians and their electorate (McQuail 2003:24). It is also easier to create suitable emotional conditioning via television because the mutual effect of sound and images can be applied. The same is possible in films but television is a much more immediate means.

The sample of the study consists of all television advertisements of Estonian major political parties from 2003-2005, 84 advertisements in total. The above timeframe was chosen because it included all direct elections at various levels held in Estonia at the time: in 2003, there was a general election; in 2004, there was a European Parliament election; in 2005, there was a municipal election. The political parties covered in the study include the Centre Party (CP), the Reform Party (R), Pro Patria (PP), the People's Union (PU), the Social Democrats (SD, they participated in the 2003 election as Moderates) and Res Publica (RP). All the parties won seats in the parliament in 2003 and all of them conducted wide-scale television campaigns. The electoral/public support to other Estonian parties is marginal.

The non-political advertisements, a total of 100, were chosen from among the award-winning advertisements of the 2002 Cannes International Advertising Festival. These advertisements were selected understanding that the information on the most modern ways of making television advertisements was available for the Estonian political campaign managers in 2003.

In addition to propaganda instruments, the application of humour and story-telling in advertisements is also analyzed since humour is considered one of the tools to make someone likeable (Kidron 2004:211). Therefore, it is possible, by using humour, to enhance the pleasantness of a communicator and also increase his/her credibility (O'Keefe 2002:190). Thus, it can be concluded that humour has a desired side-effect: if it is possible to make people smile, it is also possible to create approval for the presented cause (Taylor 2004:51). The presence of story-telling is analyzed because stories enable to attract and hold people's attention while the message is presented.

\footnotetext{
${ }^{2}$ Institute for Propaganda Analysis. How to Detect Propaganda // Propaganda. Edited by Robert Jackall. New York University Press 1995. pp 217-223. Reprinted from Propaganda Analysis, vol. 1, no. 2, 1937
} 
The author employed content analysis when studying the sample. The method is considered to be suitable for establishing differences and similarities (Kleinstauber 2004:68). According to the classical definition, content analysis is a research technique for the objective, systematic and quantitative description of the manifest content of communicative messages (Berelson 1952:18, cited in Bryman 2001:178). It is common to use the research technique for analyzing the content of messages intended for broad audiences (Neuendorf 2002:22) and specifically for propagandistic messages (Krippendorff 2004:8). During the World War II, it was believed that it was possible to manipulate masses with messages disseminated via mass communication channels, and quantitative content analysis was partly developed for scientists and politicians to be aware of symbolic aspects of mass culture and to identify propagandistic messages and their influence (Deacon et al 1999:115-116). It is characteristic of content analysis that the researcher presents the research question, not the hypothesis (Krippendorff 2004:32).

Content analysis has also its limitations. The technique enables the researcher to gather and compare data but it is not possible to explain the findings and the causal relations between the different aspects of messages (Bignell 2004:211). Another limitation is that content analysis is not suitable for analyzing the effects of the message (Sumser 2001:199). Also, it is difficult to answer the question why and inevitably the codebooks leave some space for interpretation (Bryman 2001:191). However, these restrictions are not important in the context of this article as the research question is formulated to find possible propaganda instruments in television advertisements and to identify the similarities and differences between political and nonpolitical advertisements, not to explain them.

\section{Concept of propaganda: core and variations}

Conceptual understanding of propaganda varies. One of the first definitions of propaganda was offered by Walter Lippmann in his book "Public Opinion" in 1922: "propaganda is an effort to alter the picture to which men respond, to substitute one social pattern for another (Lippmann 1997:16). In 1928, Edward Bernays defined propaganda as a consistent, enduring effort to create or shape events to influence the relations of the public to an enterprise, idea or group (Bernays 2004:52). In 1934, Harold D. Lasswell defined propaganda in its broadest sense as the technique of influencing human action by the manipulation of representations (Lasswell 1995:1). These were the three most important propaganda definitions before the World War II. Thus, in the first half of the $20^{\text {th }}$ century, it was not yet agreed whether propaganda was an action or a formation of techniques. It was clear, however, that the aim of propaganda was to influence people.

Such a dual view of the concept of propaganda continued after the World War II. One of the most influential writers about propaganda in the post-war period, Jacques Ellul, defined propaganda as a set of methods employed by an organized group that wants to bring about the active or passive participation in its actions of a mass of individuals, psychologically unified through psychological manipulations and incorporated in an organization (Ellul 1973:61). However, the understanding that propaganda is a set of methods did not prevail. Garth S. Jowett and Victoria O'Donnell, two frequently quoted propaganda theorists of the late $20^{\text {th }}$ century, define propaganda as the deliberate, systematic attempt to shape perceptions, manipulate cognitions, and direct behavior to achieve a response that furthers the desired intent of the propagandist (Jowett and O’Donnell 1999:6).

The above definitions allow drawing conclusions about certain characteristics of propaganda (Table 1): the aim of the propagandist is to influence the attitudes and behaviour of the target 
group formed of individuals who are an integrated part of the society; the propagandist tries to manipulate both the way people perceive the reality and also the way their emotions are created from these perceptions of reality.

Based on the above definitions, propaganda is understood in this article as shaping of the attitudes and behaviour of a person in a way desired by the propagandist. The person is considered to be an integrated part of the public and the propagandist's arguments are derived from the socio-cultural context, based on symbols and stereotypes and targeted at emotions.

Table 1

The characteristics of propaganda

\begin{tabular}{|c|c|c|c|c|}
\hline Author & $\begin{array}{c}\text { Altering } \\
\text { attitudes/ } \\
\text { behaviour }\end{array}$ & $\begin{array}{c}\text { Manipulating } \\
\text { reality }\end{array}$ & $\begin{array}{c}\text { Target } \\
\text { group }\end{array}$ & $\begin{array}{c}\text { Activity/Set of } \\
\text { methods }\end{array}$ \\
\hline Walter Lipmann & $\begin{array}{c}\text { Altering } \\
\text { attitudes }\end{array}$ & $\begin{array}{c}\text { Forming social } \\
\text { patterns }\end{array}$ & People & Activity \\
\hline Edward Bernays & $\begin{array}{c}\text { Altering } \\
\text { attitudes }\end{array}$ & Altering relations & Public & Activity \\
\hline Harold Lasswell & $\begin{array}{c}\text { Altering } \\
\text { both }\end{array}$ & $\begin{array}{c}\text { Manipulation of } \\
\text { representations }\end{array}$ & People & Technique \\
\hline Jacques Ellul & $\begin{array}{c}\text { Altering } \\
\text { both }\end{array}$ & $\begin{array}{c}\text { Psychological } \\
\text { manipulations }\end{array}$ & $\begin{array}{c}\text { Organized } \\
\text { group }\end{array}$ & Set of methods \\
\hline $\begin{array}{c}\text { Garth Jowett \& } \\
\text { Victoria O’Donnell }\end{array}$ & $\begin{array}{c}\text { Altering } \\
\text { both }\end{array}$ & $\begin{array}{c}\text { Manipulate } \\
\text { cognitions }\end{array}$ & People & Activity \\
\hline
\end{tabular}

For better understanding of propaganda, the author has constructed a propaganda model (Figure 1). The socio-cultural context is considered to be the basis of propaganda. The sociocultural context, and propagandist and mass media influence each another. Everything done during a propaganda campaign influences the socio-cultural context and this has to be taken into account when planning future actions. Influencing the context is defined as a social propaganda or pre-propaganda. Its aim is not to induce immediate change in action but to prepare the ground for that, and to insist on the attitudes favourable for the propagandist while reducing the impact of the unfavourable attitudes.

In modern societies the information flow (I) is open. This means that an essential characteristic of totalitarian propaganda, - censorship (Bartlett 1940:13-14) - is no longer valid because massive censoring of information is almost impossible. In modern societies censorship is superseded by manipulating the interpretations of facts. In other words, the propagandist interprets events, objects and arguments in the way most suitable for him. Also, he tries to enhance the credibility of favourable sources and disregard possible opposition with a myth. The facts, the data, the reasoning - all are forgotten and only the impression remains (Ellul 1973:86). Therefore, the task of the propagandist is to create an irrational reaction based on rational and factual arguments so that the target group would act in the way desired by the propagandist (Uudelepp 2005).

Propaganda must cover all intellectual and emotional aspects of everyday life; there must be no way of escaping the propagandistic message. The most effective means for reaching the 
public is mass media. Personal contacts are also considered to be valuable, especially while communicating with opinion leaders $(\mathrm{O})$.

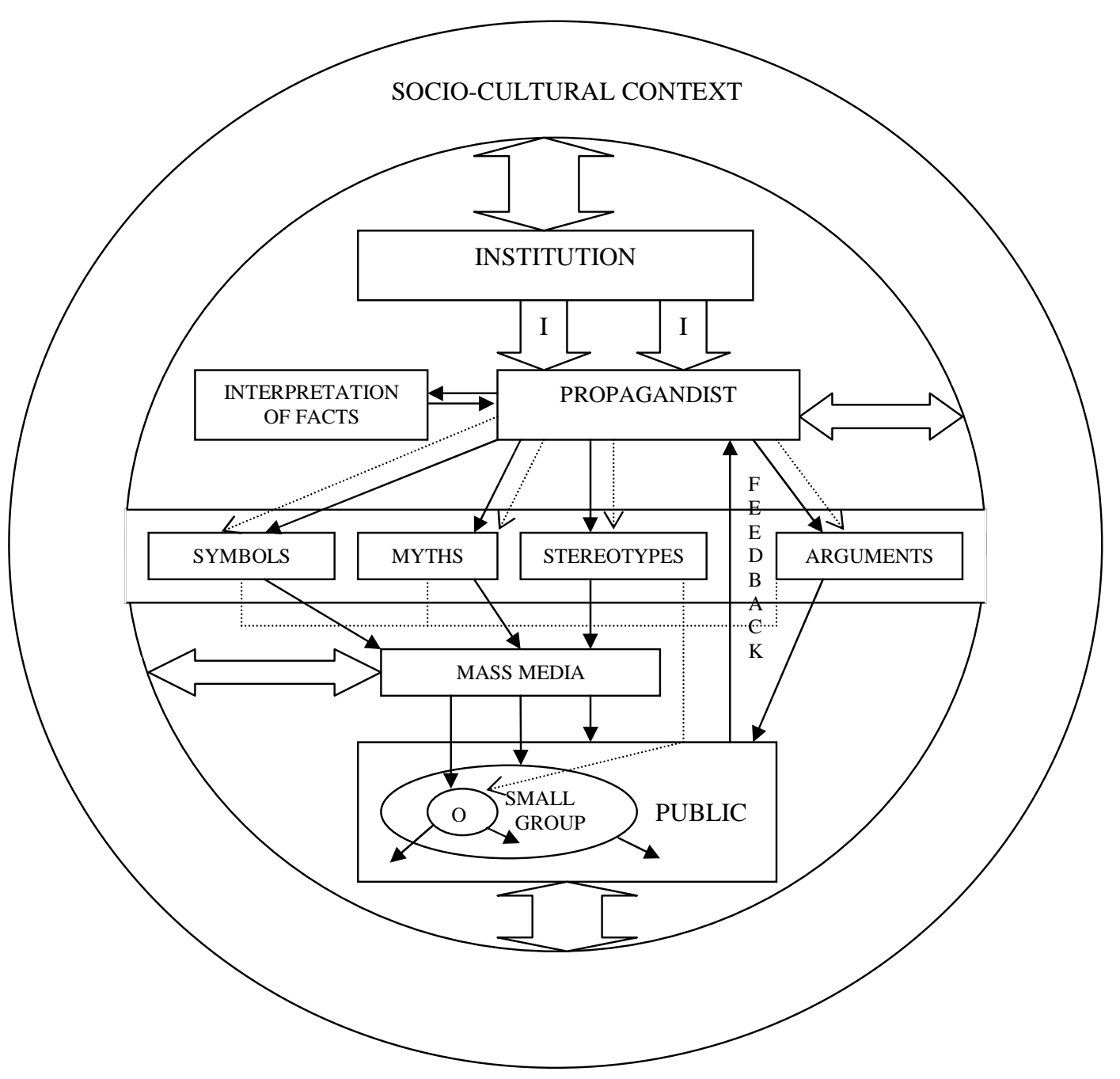

Figure 1. Model of a contemporary propaganda

Source: Uudelepp, 2005

According to the definition, the aim of propaganda is to shape attitudes and behaviour. Both components are equally important. Social propaganda is used to shape attitudes in the way favourable to the propagandist and, by that, the atmosphere for calls to action is created. Then it is easier for the propagandist to manipulate people's behaviour in the desired way. Every person is considered to be an active part of the society interacting with other people both within his/her social group and outside of it. By doing that, he/she filters new messages. The propagandist needs to create the circumstances where the group is ready to support his/her messages and diminish the importance of competing messages. 


\section{Developing conceptual basis for propaganda instruments}

According to the above propaganda model, there are three different sets of instruments for possible manipulation. The first set is derived from the socio-cultural context. It is cognitive and based on simplification - complex issues are simplified and made easily comprehensible. This level is based on symbols and stereotypes upon which propagandistic arguments are built. It allows the propagandist to manipulate the way we perceive those symbols and adapt stereotypes. The importance of symbols in propaganda is based on the understanding that ideological signs are connected more to symbols and less to issues (Conover and Feldman 2004:213). This connection between propaganda and ideology is important because propaganda is commonly understood as discourse serving ideology (Burnett 1989:127).

The meaning of symbols is essentially social and the meanings are altering with persons (Millar and Millar 1976:4). Thus, no symbol has an essential connection with the meaning ascribed to it. This is an opportunity for propagandists to establish connections that suit their aims. Stereotypes are closely connected with symbols. Stereotypes are generalizations, particularly the attribution to an individual of characteristics ascribed as universal to a group from which that individual is drawn (O'Shaughnessy 2004:57). The importance of stereotypes in propaganda has been known for a long time; stereotypes were the cornerstone of Lippmann's writings about public opinion and propaganda. He wrote that in the world overflowing with information people are searching for the first familiar sign and after that stereotypes fitting to that sign are applied (Lippmann 1997:59).

The second set is social and based on people's need to identify oneself and become part of the society. It is possible to guide people's behaviour by directing them to act according to the role model set by the élite and opinion leaders or by the fellow members of their social group. Explicit ideological self-knowledge is not common, usually it is limited to rulers, opinion leaders and other members of the élite (van Dijk 2005:121). Classic propaganda is vertical its source is the leader, the political or religious head who acts from the superior position of his authority and seeks to influence the crowd below (Ellul 1973:80). The assumption that the ruling elite can indoctrinate and manipulate people the way suitable for the élite is based on that (Lukes 1988:77) and when experts alter their ideological understanding the public will follow after some period of time (Zaller 1992:328). If there is no example from trusted leaders, people tend to base their decisions on how to behave and what to think on the values presented by the other members of the same social group. This means that people tend to decide on the right and wrong relying on others (Cialdini 2005:121). In totalitarian propaganda, it was one of the core statements.

The third set is based on the different ways of selecting suitable information and is, therefore, technological. It is based on either censorship or on manipulating with facts and their interpretation. In the Interwar period, it was agreed that successful propaganda is impossible without effective censorship (Lippmann 1997:28, Bartlett 1940:13). Censorship is still present in modern societies but its forms have changed. Media chooses "facts" that are in accordance with the interests of the élite or attract public attention thus influencing mental models of the broader public while the possibilities for minorities to present their cause in the mass media is limited (van Dijk 2005:218). As applying censorship is not possible for every propagandistic body and direct lying is difficult, censorship is, in most part, replaced by manipulation of interpretations of facts. For example, Ellul claimed (Ellul 1973:52) that direct lying must be avoided but the propagandist is free to manipulate with context and presentation of facts. 


\section{Typology of propaganda instruments}

Hence, it is possible to develop a certain typology of propaganda instruments. Table 2 presents the instruments, their connection with classic propaganda devices, propaganda techniques $^{3}$ and possible indicators for every technique. The table is a summary of the research instrument for the content analysis of the present study.

Table 2

Propaganda instruments, their bases and indicators

\begin{tabular}{|c|c|c|c|c|}
\hline $\begin{array}{l}\text { Bases of } \\
\text { instruments }\end{array}$ & $\begin{array}{l}\text { Propaganda } \\
\text { instruments }\end{array}$ & $\begin{array}{l}\text { Classic } \\
\text { propaganda } \\
\text { devices }\end{array}$ & Propaganda techniques & Possible indicators \\
\hline \multirow{7}{*}{$\begin{array}{l}\text { Symbols } \\
\text { and } \\
\text { stereotypes }\end{array}$} & \multirow{7}{*}{$\begin{array}{l}\text { Cognitive } \\
\text { propaganda } \\
\text { instruments } \\
(\mathrm{CPI})\end{array}$} & \multirow[t]{2}{*}{ Name calling } & 1. Ad hominem arguments & $\begin{array}{l}\text { Greedy, } \\
\text { unintelligent etc }\end{array}$ \\
\hline & & & 2. Ridiculing & $\begin{array}{l}\text { Comparison with } \\
\text { animal etc }\end{array}$ \\
\hline & & \multirow{3}{*}{$\begin{array}{l}\text { Glittering } \\
\text { generalities }\end{array}$} & $\begin{array}{l}\text { 3. Selection of emotionally } \\
\text { appealing words }\end{array}$ & $\begin{array}{l}\text { Best, new, future } \\
\text { etc }\end{array}$ \\
\hline & & & $\begin{array}{l}\text { 4. Selection of emotionally } \\
\text { appealing images }\end{array}$ & $\begin{array}{l}\text { Children, animals, } \\
\text { sun etc }\end{array}$ \\
\hline & & & 5. Calls for altruism & $\begin{array}{l}\text { Claiming that } \\
\text { person is good etc }\end{array}$ \\
\hline & & \multirow[t]{2}{*}{ Transfer } & $\begin{array}{l}\text { 6. Referring to accepted } \\
\text { symbols }\end{array}$ & $\begin{array}{l}\text { University, } \\
\text { church, flag etc }\end{array}$ \\
\hline & & & $\begin{array}{l}\text { 7. Referring to accepted } \\
\text { professions }\end{array}$ & $\begin{array}{l}\text { Doctors, judges, } \\
\text { teachers etc }\end{array}$ \\
\hline \multirow{6}{*}{$\begin{array}{l}\text { Influence of } \\
\text { élite or } \\
\text { social group }\end{array}$} & \multirow{6}{*}{$\begin{array}{l}\text { Social } \\
\text { propaganda } \\
\text { instruments } \\
\text { (SPI) }\end{array}$} & \multirow[t]{2}{*}{ Testimonial } & $\begin{array}{l}\text { 1. Emphasizing on } \\
\text { authority }\end{array}$ & $\begin{array}{l}\text { Scientist, Cabinet } \\
\text { Minister etc }\end{array}$ \\
\hline & & & $\begin{array}{l}\text { 2. Emphasizing on } \\
\text { celebrity }\end{array}$ & $\begin{array}{l}\text { Sports star, singer } \\
\text { etc }\end{array}$ \\
\hline & & \multirow[b]{2}{*}{ Plain Folks } & $\begin{array}{l}\text { 3. Image based on target } \\
\text { audience }\end{array}$ & $\begin{array}{l}\text { Clothing, haircut } \\
\text { etc }\end{array}$ \\
\hline & & & $\begin{array}{l}\text { 4. Behaviour based on } \\
\text { target audience }\end{array}$ & $\begin{array}{l}\text { Visiting same } \\
\text { market etc }\end{array}$ \\
\hline & & \multirow[b]{2}{*}{ Band wagon } & $\begin{array}{l}\text { 5. Creation of confident } \\
\text { image }\end{array}$ & $\begin{array}{l}\text { Lots of followers } \\
\text { on image etc }\end{array}$ \\
\hline & & & 6. Utilization of absolutes & $\begin{array}{l}\text { Always, } \\
\text { everybody etc }\end{array}$ \\
\hline \multirow{4}{*}{$\begin{array}{l}\text { Distortion } \\
\text { of reality }\end{array}$} & \multirow{4}{*}{$\begin{array}{l}\text { Technological } \\
\text { propaganda } \\
\text { instruments } \\
\text { (TPI) }\end{array}$} & \multirow{4}{*}{ Card stacking } & 1. False inductivity & $\begin{array}{l}\text { Sample too small } \\
\text { etc }\end{array}$ \\
\hline & & & 2. False causality & $\begin{array}{l}\text { Switching cause } \\
\text { and effect }\end{array}$ \\
\hline & & & 3. Oversimplification & $\begin{array}{l}\text { Creating false } \\
\text { dichotomy }\end{array}$ \\
\hline & & & $\begin{array}{l}\text { 4. Manipulating with } \\
\text { numbers }\end{array}$ & $\begin{array}{l}\text { Mixing } \\
\text { percentages etc }\end{array}$ \\
\hline
\end{tabular}

\footnotetext{
${ }^{3}$ The propaganda techniques are based on Henry T. Conserva's book „Propaganda Techniques“.
} 
We can conclude from the table that there are two contradictory categories: élite vs. social group and benefiting from patterns of cognitive process vs. distortion of input to cognitive process. Based on these two pairs, the author has constructed the axis of propaganda (Figure 2).

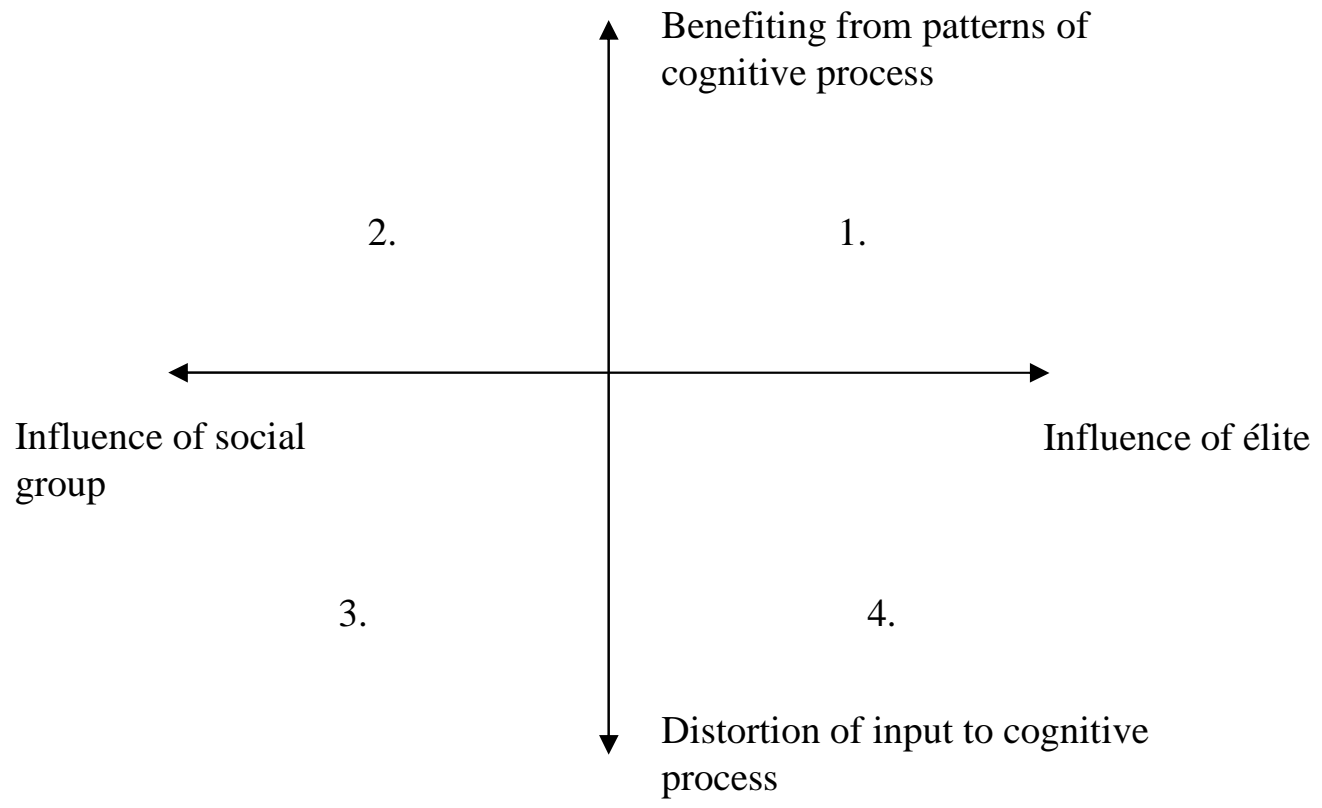

Figure 2. The axis of propaganda

There are four possible types of propagandistic messages according to the axis:

1. The message is based mostly on the socio-cultural context and the example of a strong leader;

2. The message is based mostly on the socio-cultural context and the example of a social group;

3. The message is based mostly on the manipulation of facts and the example of a strong leader;

4. The message is based mostly on the manipulation of facts and the example of a social group.

\section{Results and discussion}

Comparison of Estonian political parties' television advertisements

The frequency per advertisement with which Estonian parties apply propaganda instruments is presented in Figure 3. It is obvious that the Centre Party, Pro Patria and Res Publica apply more propaganda instruments per advertisement than the remaining three parties that use propaganda in relatively similar proportions. The Centre Party and the Reform Party are the only two employing technological propaganda instruments. 


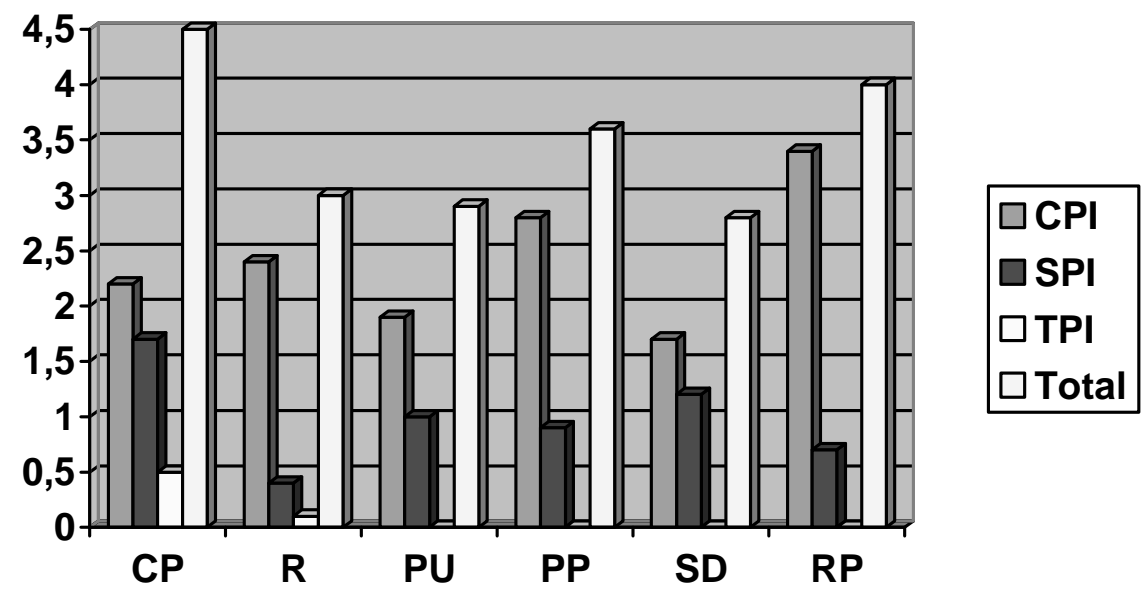

Figure 3 The average representation of propaganda instruments in political television advertisements

All parties use cognitive propaganda instruments more frequently than other types of instruments. The Reform Party and Res Publica employ cognitive instruments the most frequently (Figure 4); the usage of cognitive instruments by Pro Patria is also above the average. The Centre Party and Social Democrats employ cognitive and social propaganda instruments in relatively similar proportions. Thus, the author draws a conclusion that the Estonian right-wing parties focus in their propagandistic television advertisements mostly on the usage of symbols accepted by the society while the centre and left-wing parties' advertisements use a more balanced proportion of cognitive and social instruments. The usage of technological propaganda instruments is limited; only in the case of the Centre Party the percentage of technological instruments employed is above 10.

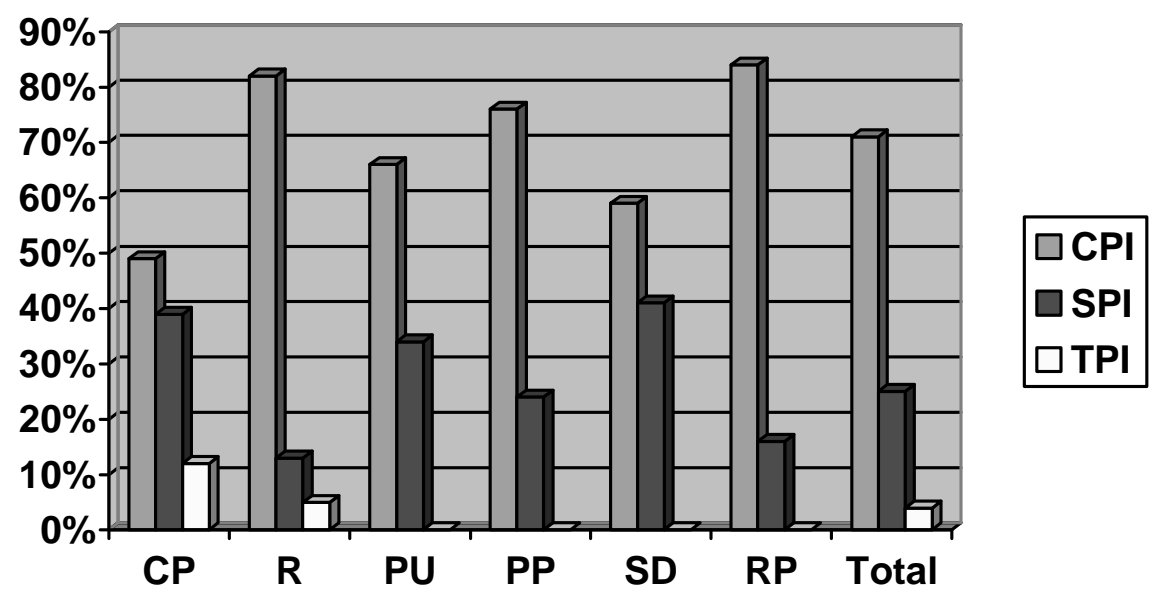

Figure 4. Division of propaganda instruments in political television advertisements

Figure 5 presents the usage of humour and story-telling. Humour is employed by the Reform Party and People's Union; story-telling is used by the Centre Party, the Reform Party and the People's Union. Other three parties have used neither. However, only the application of humour in the Reform Party's advertisements can be considered deliberate; story-telling in the 
Centre Party's advertisements and both humour and story-telling in the People's Union's advertisements are casual.

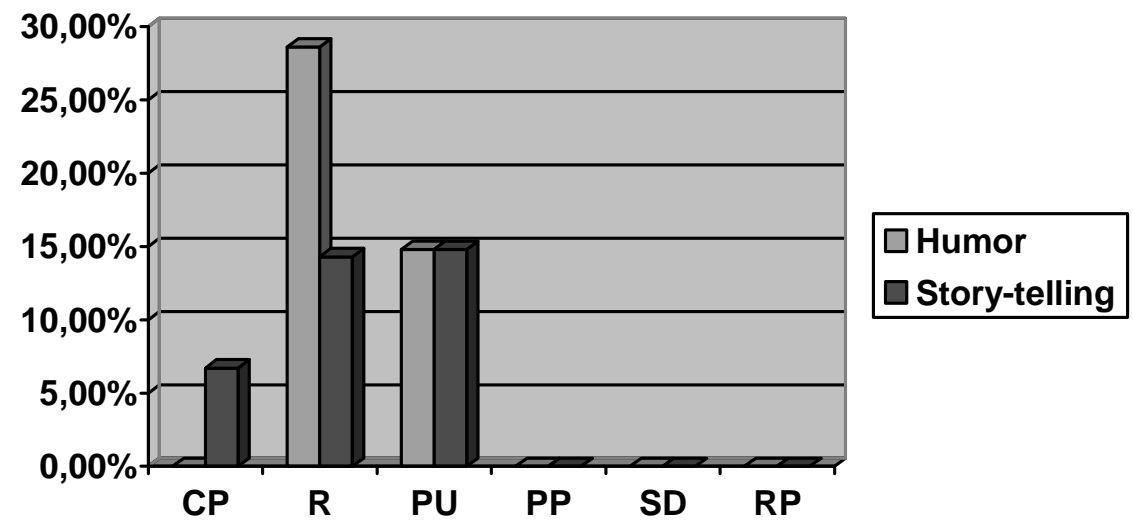

Figure 5. Humour and story-telling in political television advertisements.

Comparison of political and non-political television advertisements

All categories of propaganda instruments were used in political television advertisements but in non-political television advertisements, technological propaganda instruments were not applied. So the further comparison of technological propaganda instruments is not possible.

Figure 6 presents the frequency of propaganda instruments per advertisement in political and non-political television advertisements. The following two major similarities become obvious:

- Cognitive propaganda instruments are more often used than social propaganda instruments;

- The application of cognitive and social propaganda instruments is similar in proportion.

Two major differences are also obvious:

- Technological propaganda instruments are not employed in non-political television advertisements;

- On average, more propaganda instruments per advertisement are applied in political television advertisements.

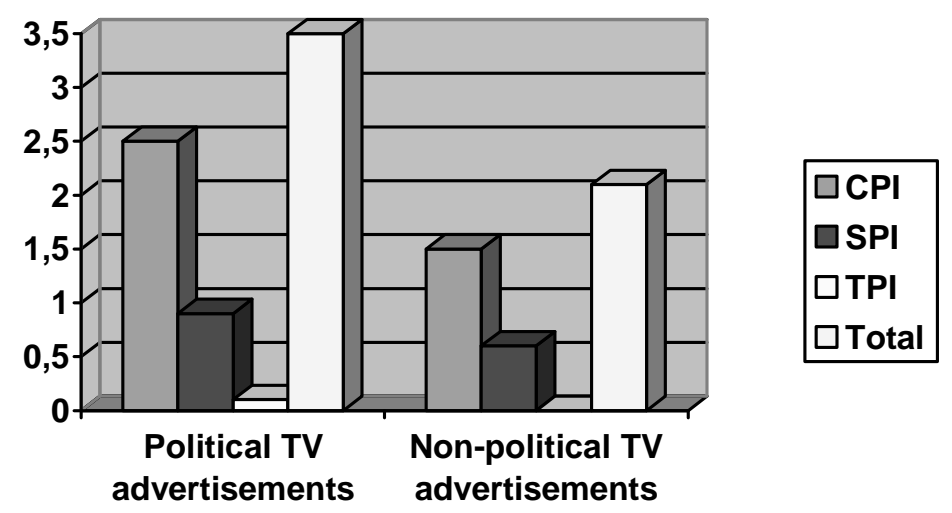


Figure 6. Average representation of propaganda instruments in political and non-political television advertisements

Figure 7 indicates that the proportion of cognitive propaganda instruments applied in political and non-political television advertisements is not only similar but practically identical. The difference in the proportional application of social propaganda instruments is marginal and caused by the fact that $4 \%$ of instruments used in political television advertisements are technological.

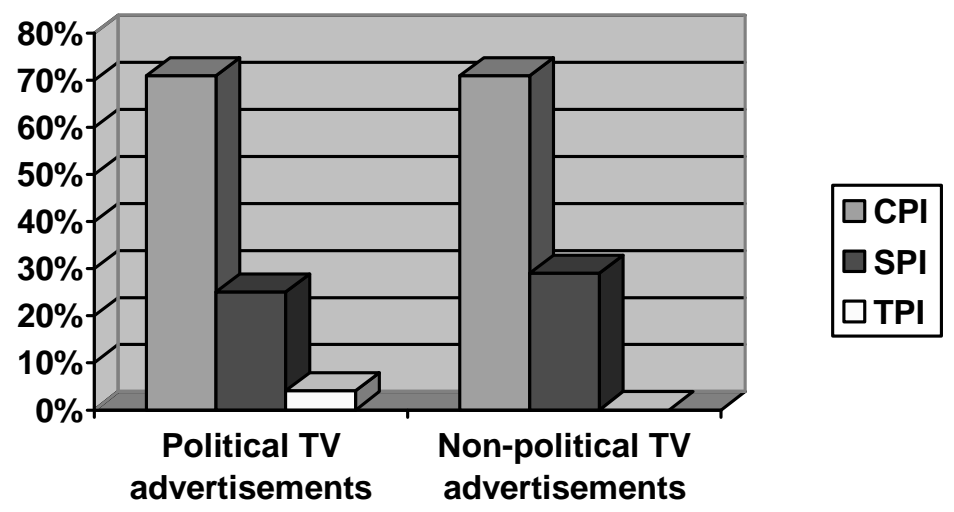

Figure 7. Proportion of propaganda instruments in political and non-political television advertisements

At the same time, there are major differences in the application of humour and story-telling (Figure 8). While in political television advertisements, the usage of humour and story-telling is rare, these instruments are in constant use in non-political television advertisements. If we consider it together with the fact that technological propaganda instruments are used only by $1 / 3$ of the sample political parties and not at all in non-political TV advertisements, would it be possible to assume that there has been a change in the set of propaganda instruments?

As pointed about above, censorship was considered a vital part of propaganda in the early $20^{\text {th }}$ century and manipulation with facts in the middle of the previous century. But perhaps technological propaganda instruments are loosing their importance in contemporary propaganda and are being replaced by instruments based on the structural aspects of propagandistic messages? These are then structural instruments which can be used to create messages suitable for commercializing media and society. In that case it is not that important in contemporary propaganda to concentrate on hiding or distorting information because the political process itself does it ${ }^{4}$. It is more important to create the message in a form that attracts attention, holds it for a time long enough to distribute symbols and information, and evokes a positive emotional memory. This is in accordance with the understanding contained in propaganda theory that propagandistic arguments and messages have to be rational but their effect has to be emotional.

\footnotetext{
${ }^{4}$ See Taylor 2003, p 86-103
} 


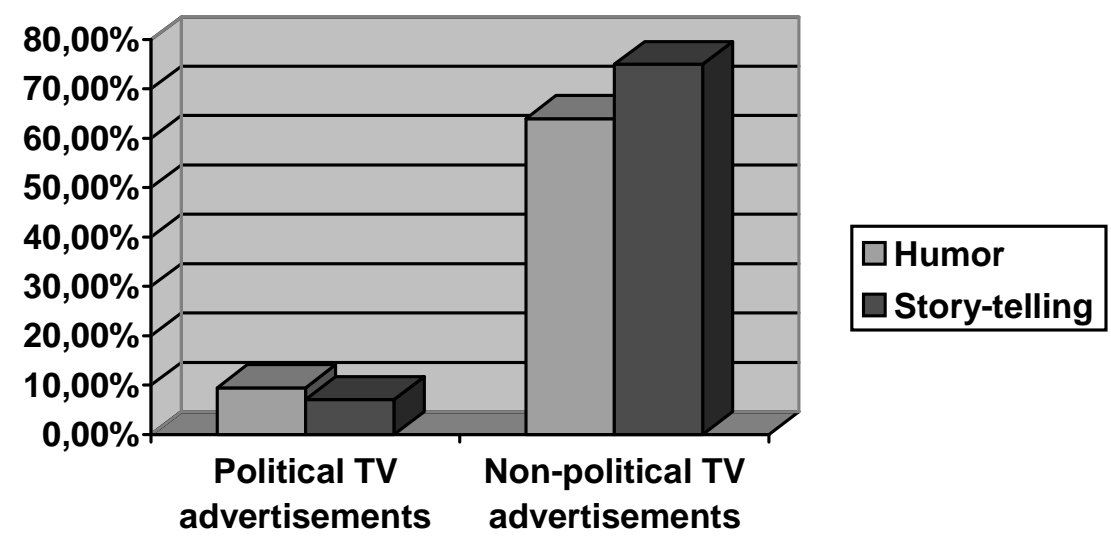

Figure 8. Humour and story-telling in political and non-political television advertisements

Based on the formulated questions and the gathered data, it is possible to place the sample political parties on the propaganda axis, and make a comparative analysis between them and the propagandistic placement of non-political advertisements. The coordinates for the placements are calculated based on the average representation of propaganda techniques in different sets of advertisements. In order to establish coordinates for the vertical axis, the average representation of technological propaganda instruments in political advertisements are subtracted from the average representation of cognitive propaganda instruments in such advertisements. To establish coordinates for the horizontal axis, the sum of the average representations of techniques based on the influence on a social group, i.e. an image based on the target audience, a behaviour based on the target audience, projecting a confident image and utilization of absolutes, is subtracted from the sum of the average representations of techniques based on the influence of the élite, i.e. emphasizing authority and recognition.

Table 5

Coordinates for placing advertisements on propaganda axis

\begin{tabular}{|l|c|c|}
\hline & Vertical axis & Horizontal axis \\
\hline Centre Party (CP) & 1.7 & -0.8 \\
\hline Reform Party (R) & 2.3 & -0.3 \\
\hline People's Union (PU) & 1.9 & 0.7 \\
\hline Pro Patria (PP) & 2.8 & 0.5 \\
\hline Social Democrats (SD) & 1.7 & 0.8 \\
\hline Res Publica (RP) & 3.4 & 0.6 \\
\hline Political TV advertisements (P) & 2.4 & 0.1 \\
\hline Non-Political TV advertisements (NP) & 1.5 & -0.6 \\
\hline
\end{tabular}

The propaganda axis shows that political parties can be divided into three groups (see Figure 9). The first group comprises the Centre Party and the Reform Party, the second group consists of Pro Patria and Res Publica, and the third of the People's Union and Social Democrats. The former two parties are placed in the quarter of the axle which shows that the propagandistic message is based mostly on the socio-cultural context and on the example of the social group. The latter four are placed in the quarter that is based mostly on the sociocultural context and on the example of the strong leader. Non-political advertisements are in the same quarter with the Centre Party and the Reform Party, and political advertisements with Pro Patria, Res Publica, the People's Union and Social Democrats. It has to be pointed 
out that the previous statement is not very informative because different parties function as each other's counterbalance; generally, political advertisements are in the centre.

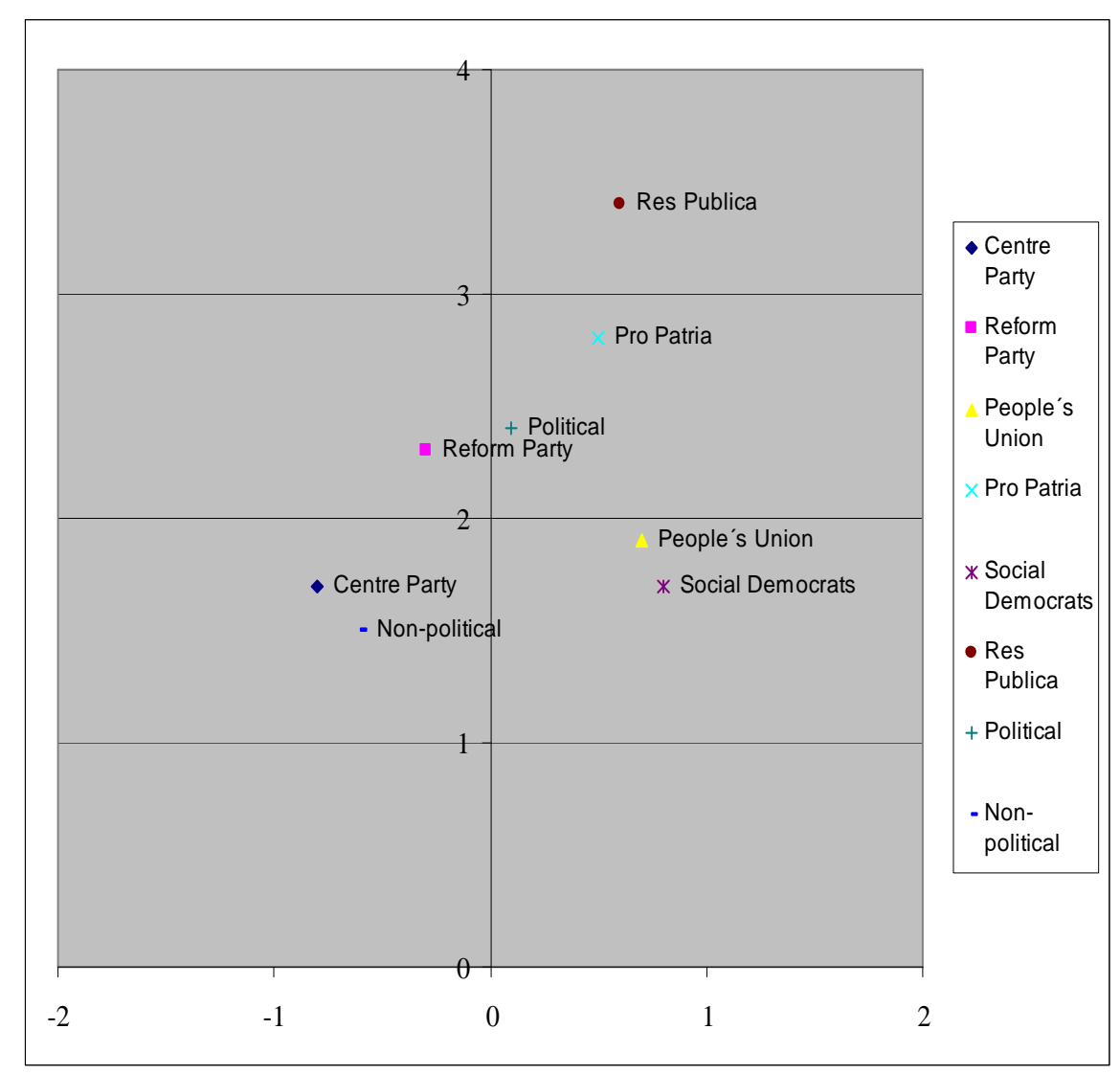

Figure 9. Placing of political parties on the propaganda axle

The placement of non-political advertisements and advertisements promoting the Centre Party and the Reform Party is interesting. It shows that two Estonian parties which have been constantly successful at elections ${ }^{5}$ form the propagandistic construction of their advertisements in a similar way to the award-winning non-political advertisements competing at the Cannes International Advertising Festival. This raises a question about possible casual relations between specific patterns of the usage of propaganda instruments and the success of persuasive communication in contemporary society.

As a result of this study, it is possible to conclude that cognitive propaganda instruments are more widely employed than social propaganda instruments. At the same time, there is no clear application pattern of cognitive instruments which might determine success in persuasive communication. The application of social instruments makes a clear difference: parties concentrating on the influence of social groups are more successful than those emphasizing the role of the élite.

In the case of the Centre Party, it brings out an interesting contradiction. According to the propaganda axis, the Centre Party is the closest to the example set by the modern award-

\footnotetext{
${ }^{5}$ The Centre Party won the 2003 and 2005 elections and came second in 2004; the Reform Party was the second in 2005, and the third in 2003 and 2004.
} 
winning television advertisements. But if we speak about a possible shift in propaganda instruments, the Centre Party is the most stagnant Estonian political party employing technological propaganda instruments more widely than all the other parties combined. This means that they still apply instruments considered no longer vital and, like all other Estonian political parties, neglect modern additions to propaganda instruments.

The second group consisting of Pro Patria and Res Publica is also interesting. These two parties merged after the 2005 election. It might indicate that parties with similar ideological background may apply propaganda instruments in a similar way. The third group consists of two parties the closest to each other on the axis - the People's Union and Social Democrats. These parties had a joint campaign in Tallinn at the 2005 election meaning that some of their television advertisements were done by the same people. That might be the reason why these two parties are placed so close.

\section{In conclusion}

This research shows that Estonian political television advertisements and international nonpolitical television advertisements share some significant similarities. Cognitive propaganda instruments are more widely employed than social or technological ones. Parties that emphasise in their advertisements the role of the influence of social groups rather than that of the élite are more successful. The role of technological propaganda instruments is diminishing and such instruments are replaced by structural ones. A major difference is that, on average, there are more propaganda instruments per advertisement in political television advertisements than in non-political television advertisements, and technological propaganda instruments are not employed in non-political television advertisements.

The author would also like to draw attention to the following questions raised as a result of his present research. First, presumably there is a connection between successful persuasive communication and ways of implementing propaganda instruments as the placement of the successful international non-political advertisements and the Estonian political propagandistic messages in the same quarter on the propaganda axle indicates.

Second, the analysis showed that Estonian political parties differ in their usage of propaganda instruments and are, thus, differently placed on the propaganda axis. There are several possible reasons:

- Different ideology, for example maybe liberal and conservative parties differ in their implementation of fact manipulations or techniques aimed at using the impact of the élite or social group 6 .

- The preferences, requests and know-how of party leaders or campaign managers.

- The background, professionalism, experience and know-how of the agency hired to make the advertisements.

Probably there is a major shift in the sets of propaganda instruments. This raises the third question: why are humour and story-telling not applied in Estonian political advertisements although they have been proved necessary at the international non-political level? There are also several possible reasons:

\footnotetext{
${ }^{6}$ Then the Reform Party and Pro Patria ,or the Centre Party and the People's Union should be intuitively similar, not the Centre Party and the Reform Party, and the People's Union and Social Democrats as the results of this research indicate.
} 
- Elections are considered to be too serious a process and, because of that, presenting the party platform in a humorous way is regarded as inappropriate.

- Agencies are not capable of writing copies for such advertisements ${ }^{7}$.

- This option has not been considered important and useful.

The fourth question concerns possibilities for further generalization. For example, are Estonian non-political television advertisements more similar to contemporary non-political or Estonian political advertisements? And whether the absence of humour and story-telling is characteristic of Estonian political advertising only or is it also commonplace in the states with a long tradition of free elections? If it is not commonplace elsewhere, maybe it is a further proof of evolution in the field of propaganda instruments?

Answering these questions requires further research and, regarding the former three questions, application of qualitative methods.

\footnotetext{
${ }^{7}$ This cause might not have a very high probability rate as the Reform Party and the People's Union have used humour in their advertisements.
} 


\section{Bibliography}

Bartlett, F. C. (1940). Political Propaganda. Cambridge University Press.

Bernays, E. (2004). Propaganda. New York: Ig Publishing. Originally published: New York, 1928

Bignell, J. (2004). An Introduction to Television Studies. London: Routledge.

Bryman, A. (2001). Social Research Methods. Oxford University Press.

Burnett, N. F. S. (1989). Ideology and Propaganda: Toward an Integrative Approach. - T. J. Smith III (Ed). Propaganda. A Pluralistic Perspective. New York: Praeger Publishers, 127138.

Cialdini, R. B. (2005). Mõjustamise psühholoogia. Teooria ja praktika. Tallinn: Pegasus. Original Title: Cialdini, R. B. 2001. Influence: Science and Practice, 4th edition. Allyn\&Bacon.

Conover, P., J. And FELDMAN, S. (2004). Origins and Meaning of Liberal/Conservative Self-Identifications. - J. T. Jost, J. Sidanius (Ed.). Political Psychology. New York: Psychology Press.

Deacon, D., PICKERING, M., GOLDING, P., MURDOCK, G. (1999). Researching Communications. A Practical Guide to Methods In Media And Cultural Analysis. Oxford University Press

Dijk, T. A. van. (2005). Ideoloogia. Tartu: Tartu Ülikooli Kirjastus.

Ellul, J. (1973). Propaganda. New York: Random House, Inc. Originaali tiitel: Propagandes. Librairie Armand Colin, 1962

Jackall, R. (1995). Propaganda. New York: University Press

Jowett, G. S., O`DONNELL, V. (1999). Propaganda and Persuasion. Sage Publications Inc.

Kaid, L., L., HOLTZ-BACHA, C. (1995). Political Advertising Across Cultures. Comparing Content, Styles, and Effects. - L. L. Kaid \& C. Holtz-Bacha (Ed.). Political Advertising in Western Democracies. Parties \& Candidates on Television. London: Sage Publications, 206227.

Kidron, A. (2004). Suhtlemine. Mondo 
Kleinsteuber, H. J. (2004). Comparing Mass Communication Systems, Media Fomrats, Media Contents, and Media Processes. - E. F. Esser, B. Pfetsch (Ed). Comparing Political Communication Theories, Cases and Challenges. Cambridge University Press.

Krippendorff, K. (2004). Content Analysis. An Introduction to Its Methodology. Thousand Oaks: Sage Publications.

Lasswell, H. D. (1995). Propaganda - R. Jackall (Ed). Propaganda. New York University Press, 13-25. Originally published in Encyclopedia of the Social Sciences, 1st edition, vol. XII. London: Macmillan, 1934

Lippmann, W. (1997). Public Opinion. Free Press Paperbacks. Originally published New York: Macmillan, 1922

Lukes, I. (1988). Radio Moscow's North American Service: A Study in Radio Propaganda. L. Bittman (Ed). Soviet Propaganda \& Disinformation Today. Pergamont-Brassey's International Defence Publishers, Inc, 77-112.

McNair, B. (1995). An Introduction to Political Communication. London: Routledge.

MCQUAIL, D. 2003. McQuaili massikommunikatsiooni teooria. Tartu: Tartu Ülikooli kirjastus. Original Title: McQuail. D. 2000. McQuail's Mass Communication Theory. 4th Edition. SAGE Publications.

Millar, D., P., MILLAR, F., E. (1976). Messages and Myths. Understanding Interpersonal Communication. New York: Alfred Publishing CO., Inc.

Neuendorf, K. A. 2002. The Content Analysis Guidebook. Thousand Oaks: Sage Publications.

O’Keefe, D., J. (2002). Persuasion. Theory \& Research. London: Sage Publications.

O’Shaughnessy, N., J. (2004). Politics and Propaganda. Weapons of Mass Seduction. Michigan: The University of Michigan Press.

Pratkanis, A., ARONSON, E. (2001). Age of Propaganda. The Everyday Use and Abuse of Persuasion. New York: W. H. Freeman and Company.

Sumser, J. (2001). A Guide to Empirical Research in Communication. Rules For Looking. Thousand Oaks: Sage Publications.

Taylor, M. (2003). Public Policy in the Community. New York: Palgrave Macmillan

Taylor, K. (2004). Brainwashing. The Science of Thought Control. Oxford: Oxford University Press.

Uudelepp, A. (2005). Propaganda Aristotelesest tänapäevani. - Riigikogu Toimetised, 11, $170-176$

Zaller, J., R. (1992). The Nature and Origins of Mass Opinion. Cambridge: The Cambridge University Press. 